\title{
Collapsed Lung
}

National Cancer Institute

\section{Source}

National Cancer Institute. Collapsed Lung. NCI Thesaurus. Code C128384.

Atelectasis of an entire lung. 